\title{
Measurement Evaluation of Pmma Laser MiCRO - MACHINING BY ANN
}

\author{
SYKOROVA, L. \& SAMEK, D.
}

Abstract: This paper presents usage of artificial neural networks for modelling of laser micro-machining process. Results of the laser micro-machining - surface quality of product and his utility in specific application - depend on the lasermachine parameters and the polymer material type. Commercial CO2 laser Mercury L-30 by LaserPro, USA was used for cutting specimens. This laser system has two parameters - power and feed. The article also shows optimization of the laser micromachining using artificial neural network. In order to interpret complicated dependencies between technological characteristics of laser micro-machining and output parameters software Matlab 6.5 with Neural Network Toolbox was used. The experimental results were evaluated and depicted into the graphs.

Key words: laser, micro-machining, surface quality, polymer material type, artificial neural network
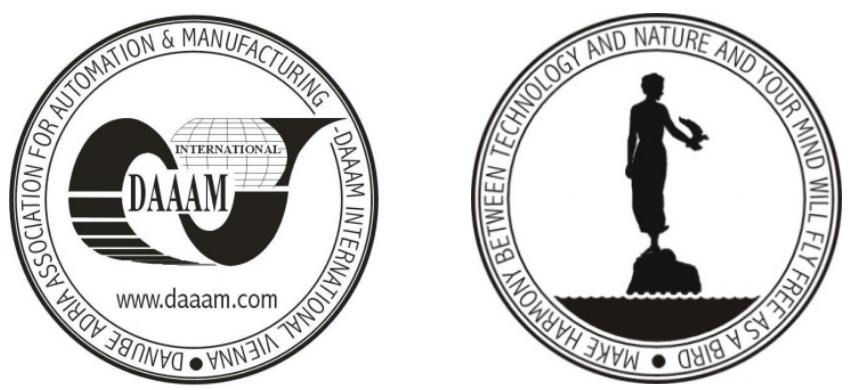

Authors' data: Sykorova, L[ibuse $]^{*}$; Dr. Samek, D[avid]**, *Tomas Bata University in Zlin, Nam. TGM 5555, 76001, Zlin, CZ, **Tomas Bata University in Zlin, nam. TGM 275, 76272, Zlin, CZ, sykorova@ft.utb.cz, samek@ft.utb.cz

This Publication has to be referred as: Sykorova, L[ibušSe] \& Samek, D[avid] (2008). Measurement Evaluation of Pmma Laser Micro - Machining by Ann, Chapter 71 in DAAAM International Scientific Book 2008, pp.873-880, B. Katalinic (Ed.), Published by DAAAM International, ISBN 978-3-901509-66-7, ISSN 1726-9687, Vienna, Austria

DOI: $10.2507 /$ daaam.scibook.2008.71 